\title{
Costs and Benefits of Foreign Direct Investment to Azerbaijan's Economy: The Case of Oil Sector
}

\author{
Gulkhanim MAMMADOVA \\ Department of Management, Fatih University \\ E-mail: m_ati@live.ru
}

\begin{abstract}
Ali COSKUN
$\mathrm{PhD}$, Associate Professor, Department of Management, Fatih University Istanbul, Turkey

E-mail: alicoskun@fatih.edu.tr
\end{abstract}

Received: March 17, 2015 Accepted: May 24, $2015 \quad$ Published: June 1, 2015

doi:10.5296/ajfa.v7i1.7260 URL: http://dx.doi.org/10.5296/ajfa.v7i1.7260

\begin{abstract}
Azerbaijan is a young republic with a developing economy. Despite the efforts of government programs and development of non-oil sectors in recent years, the oil sector is still the most important sector of the economy. Improvement in the oil sector is the main source of the developments in Azerbaijan's economy. In this study, we present the role of the oil sector in Azerbaijan's economy, investigate the foreign direct investment in Azerbaijan oil sector and analyze the costs and benefits of foreign direct investment in oil industry to the Azerbaijan's economy. After a broad literature review, it is found that foreign direct investment in Azerbaijan oil sector results in some minor costs to economy such as crowding out, negative wage spillover, profit repatriation and dual economy effect. On the other hand, foreign direct investment in Azerbaijan oil sector has great benefits for the economy, especially in terms of significant developments at macroeconomic indicators such as rapid increase in GDP. Adding to economic growth, human capital contribution, competition level, technology transfer and management and governance practices are some other benefits of foreign direct investment in Azerbaijan oil sector in Azerbaijan's economy.
\end{abstract}

Keywords: Foreign Direct Investment, FDI, Azerbaijan, Oil Sector, Cost and Benefit Analysis

JEL Code Classification: F21, O11, P33 


\section{Introduction}

The Republic of Azerbaijan is a young country founded after the collapse of the Soviet Union in 1991. After gaining independence, the country faced some important issues such as economic shortage and political conflicts with neighbors. Although the country has established a democratic political structure and solved most of the political problems, the country continues to have economic difficulties. In order to solve economic problems, governments focused on rich oil reserves in the country. Azerbaijan has started to produce and export oil, signed important agreements and developed pipeline projects. Especially after the beginning of $2000 \mathrm{~s}$, the country experienced a great deal of economic development. The government introduced programs to develop both oil and non-oil sectors. However, it must be admitted that the oil sector is still vital for Azerbaijan economy. Public services such as education, military, infrastructure etc. are financed by income from oil exports. Because it depends on oil exports, the country strived to have a great deal of reserves. The rich oil reserves attracted foreign investors to the country. With the contributions of the foreign direct investment in Azerbaijan oil sector, economic indicators of the country improved as well. In the study, the costs and benefits of foreign direct investment in oil sector on the Azerbaijan economy are investigated.

\section{Azerbaijan Oil Sector}

After gaining independence in 1991, Azerbaijan has tried hard to apply liberalization and free market economy. There have been various reforms for transitioning the economy to free market economy. Establishing new economic system, it was unavoidable to use natural sources in the Caspian Sea, with the country having to focus on the oil and natural gas underneath. Governors made several steps for using natural sources in order to reach economic targets (Aras \& Suleymanov, 2012).

Proven recoverable oil reserves of Azerbaijan at the end of 2011 reported to be 7 billion barrels (World Energy Council, 2013). In 2012, there was a production of 930,000 barrels per day (bbl/d). Azerbaijan consumed 85,000 bbl/d of that amount. In 2012, Azerbaijan was one of the top 20 oil exporters in the world. Azerbaijan has a long history of oil production and a great significance in the development of oil sector in today`s world (U.S. Energy Information Administration, 2013).

Table 1 shows amount of oil and gas sector in Azerbaijan economy. It is seen as a fact that the oil industry has vital importance for the Azerbaijan economy. The sector has great influence on the economy, especially after political stabilization in the country and oil contracts signed. All statistical data shows that Azerbaijan's economy started to develop with the beginning of the 2000s. From 2003 to 2009, as Azerbaijan started to seriously develop its oil and gas sector, GDP growth averaged $16 \%$ a year due to strong investment in this sector. Strong oil and gas production gains, high international oil prices and sharply higher public spending propelled growth to an average of $27 \%$ a year between 2003 and 2009. Oil revenues even increased more than predicted due to the spike in oil prices in world markets between 2005 and 2008, leading the country's currency reserves to reach 18 billion USD by the end of 2008 - twice its foreign debt. The oil sector accounted for $42 \%$ of value added (of GDP), $90.7 \%$ of total gross 
exports and $83.9 \%$ of total foreign investment in 2009 (World Bank, 2012).

Table 1. GDP production in the section of oil and non-oil of economy (Volume of GDP, at current prices, million manats)

\begin{tabular}{|c|c|c|c|}
\hline Years & Total GDP & Oil-gas sector & Percentage \\
\hline 2000 & $4,718.1$ & $1,371.0$ & $29.1 \%$ \\
\hline 2001 & $5,315.6$ & $1,668.2$ & $31.4 \%$ \\
\hline 2002 & $6,062.5$ & $1,882.3$ & $31.0 \%$ \\
\hline 2003 & $7,146.5$ & $2,149.1$ & $30.1 \%$ \\
\hline 2004 & $8,530.2$ & $2,672.0$ & $31.3 \%$ \\
\hline 2005 & $12,522.5$ & $5,520.9$ & $44.1 \%$ \\
\hline 2006 & $18,746.2$ & $10,091.8$ & $53.8 \%$ \\
\hline 2007 & $28,360.5$ & $15,914.2$ & $56.1 \%$ \\
\hline 2008 & $40,137.2$ & $22,251.3$ & $55.4 \%$ \\
\hline 2009 & $35,601.5$ & $16,065.5$ & $45.1 \%$ \\
\hline 2010 & $42,465.0$ & $20,409.5$ & $48.1 \%$ \\
\hline 2011 & $52,082.0$ & $25,829.9$ & $49.6 \%$ \\
\hline 2012 & $54,743.7$ & $24,487.3$ & $44.7 \%$ \\
\hline 2013 & $57,708.2$ & $24,035.1$ & $41.6 \%$ \\
\hline
\end{tabular}

Source: The State Statistical Committee of the Republic of Azerbaijan (2014a).

As it's seen in Table 2, the oil-related products have the highest share in exports. The general policy of Azerbaijan about the oil sector is selling oil, earning money and using that money for social and economic development of the country. All data gathered throughout the study also showed that Azerbaijan made great social and economic development thanks to oil profits. In other words, Azerbaijan is using oil policy in a good manner. All those facts make government to support foreign investment in oil sector.

Table 2. Exports of Main Commodities in 2013

\begin{tabular}{|l|r|r|}
\hline Commodities & \multicolumn{1}{|c|}{ Quantity } & Value (thousand USD) \\
\hline Crude petroleum. thsd. tons & 24,855 & $20,244,052$ \\
\hline Diesel fuel. thsd. tons & 1,084 & 865,353 \\
\hline Sugar. thsd. tons & 2,493 & 243,642 \\
\hline Kerosene. Tons & 252,920 & 233,300 \\
\hline Fresh fruits. Tons & 173,239 & 173,311 \\
\hline Vegetable oil. Tons & 36,992 & 110,009 \\
\hline Rough aluminum. Tons & 54,304 & 81,882 \\
\hline Polymers of ethylene, in primary forms. Tons & 65,572 & 75,810 \\
\hline Natural gas. mln. Cubic meter & 3,035 & 70,980 \\
\hline Black oil fuel. thsd. Tons & 228 & 60,127 \\
\hline Fresh vegetables. Tons & 65,518 & 55,595 \\
\hline Other items & & 391,839 \\
\hline
\end{tabular}

Source: The State Statistical Committee of the Republic of Azerbaijan (2014b). 


\section{Foreign Direct Investment in Azerbaijan}

In general, foreign direct investment (FDI) is desired by most developing countries, and governments prepare economic programs for fostering foreign direct investment in their country. FDI provides an improvement opportunity for business and economy as a whole. FDI is one of the driving forces in the integration of developing countries into the globalization process. (Ilgun \& Coskun, 2009) The interest to the FDI is especially competitive among emerging and newly established countries, such as those of the former Soviet Union (Festervand, 2011). Azerbaijan is one of these countries, with the rich oil reserves that attract the foreign investors to the country. According to the State Statistical Committee of the Republic of Azerbaijan (2014c), there is a great increase in the amount of foreign direct investment in Azerbaijan. While the total amount of foreign direct investment was 1,092 million USD in 2001, the amount exceeded 10,000 million USD in 2013. Figure 1 shows the growth in total amount of foreign investment in Azerbaijan in the last two decades.

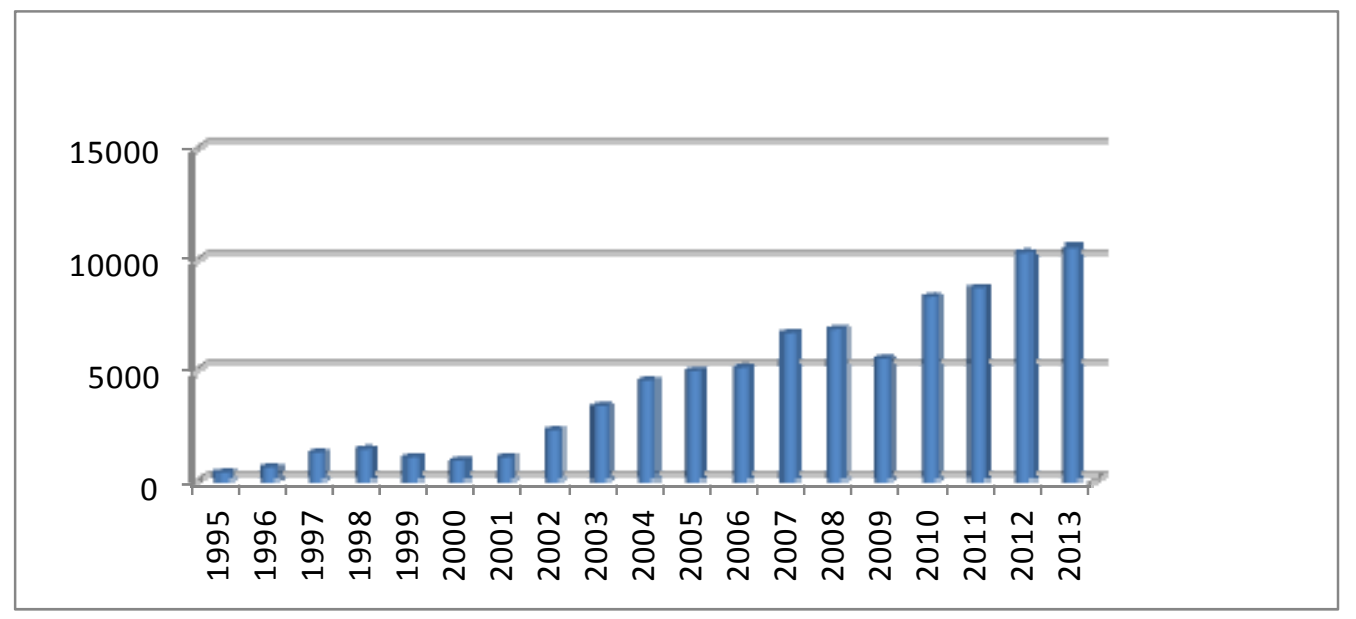

Figure 1. Total Amount of Foreign Investment in Azerbaijan

Source: Prepared with the data gathered from national statistics center of Azerbaijan

Western public and foreign investors see Azerbaijan as a predictable and responsible partner. Azerbaijan has become a good destination for investors as a result of support of Azerbaijan government. After restoration of its independence in 1991, Azerbaijan tried hard to take part in the international community, and there has been an active policy of the country. That situation was supported with increasing socioeconomic indicators (Information Digest, 2007: 72).

It is an accepted fact that foreign direct investment plays a crucial role for economic development of a country. For that reason, countries try hard to attract foreign direct investment. Azerbaijan has a successful foreign direct investment policy with low inflation rates and other economic indicators. Adding contracts signed with other companies and countries, Azerbaijan oil has become a good investment direction for investors (Pashayev, 2013). Several reasons may be claimed for increase in amount of foreign investment in Azerbaijan. All in all, it is known that there is not a discriminative regime in Azerbaijan for foreign investors. It is easy to make investment in Azerbaijan. Privatization and banking are 
open sectors for investors (Information Digest, 2007).

It must also be admitted that there are some problems faced during foreign investment as well. For example, there is a serious problem about bureaucracy in Azerbaijan. Moreover, corruption is also a problem seen in Azerbaijan. Nowadays, there are some measures to be taken and Azerbaijan government has a great anti-corruption campaign (Rosenblum, 2011).

Despite Government of Azerbaijan's desires to see foreign direct investment in country, some people in the government do not consider it as a key factor for development. Laws have always supported foreign direct investment in the country; however, there are some problems. For example, predatory behavior of politically connected elites, corruption, weak legal institutions and complex government bureaucracy makes it difficult to make investments (Bureau of Economic and Business Affairs, 2013).

Other problems faced by investors are tax rates and access to finance. Three out of four entrepreneurs experience difficulties while seeking financing. The limited availability of credit funding, restrictive conditions, high interest rates and expensive processing of payments make loans unattractive for entrepreneurs. Lack of financing to invest in new technologies and equipment makes local entrepreneurs less competitive in terms of quality than international suppliers (Ciarreta \& Nassirov, 2012: 4).

\section{Foreign Direct Investment in Azerbaijan Oil Sector}

Foreign direct investment has always been important for the last decade for Azerbaijan economy. Foreign direct investment, especially seen at hydrocarbons, is a vital contribution of economic growth of the country with the support of public investment. Oil sector has an important role in foreign direct investment in the country. It can be claimed that the decrease in investment in oil sector may have resulted in decrease in foreign direct investment in country (Center for Energy Economics 2003: 2).

An important portion of the foreign direct investment in the country focuses on oil sector. Foreign direct investment in the country is mainly motivated by resource-seeking industries. Global oil industry is an important investor in Azerbaijan. Despite the fact that oil sector is the attraction point of foreign direct investment, it is impossible to claim that oil sector is the sole factor of this situation. It will be beneficial to mention again that there is a good climate in the country for investors supported by government programs (Frayne, 2012: 4). Table 3 shows foreign direct investment in Azerbaijan in last two decades.

According to primary data during 2013, the country received 10.5 billion USD foreign investments from foreign countries and their companies, with $46.8 \%$ of them directed to the oil sector (The State Statistical Committee of the Republic of Azerbaijan, 2014c). 
Table 3. Foreign Direct Investment in Azerbaijan Economy (Million USD)

\begin{tabular}{|l|c|c|c|c|}
\hline & $\begin{array}{c}\text { Total foreign } \\
\text { direct investment }\end{array}$ & $\begin{array}{c}\text { Financial } \\
\text { credits }\end{array}$ & Oil industry & $\begin{array}{c}\text { Companies with } \\
\text { joint and foreign } \\
\text { investment }\end{array}$ \\
\hline $\mathbf{1 9 9 5}$ & 375.1 & 220.4 & 139.8 & 14.9 \\
\hline $\mathbf{2 0 0 0}$ & 927.0 & 262.9 & 546.1 & 118.0 \\
\hline $\mathbf{2 0 0 5}$ & $4,893.2$ & 698.4 & $3,799.9$ & 230.5 \\
\hline $\mathbf{2 0 0 6}$ & $5,052.8$ & 983.5 & $3,422.3$ & 368.4 \\
\hline $\mathbf{2 0 0 7}$ & $6,674.3$ & $1,576.6$ & $4,003.3$ & 439.1 \\
\hline $\mathbf{2 0 0 8}$ & $6,847.4$ & $2,357.9$ & $3,350.7$ & 494.1 \\
\hline $\mathbf{2 0 0 9}$ & $5,468.6$ & $1,438.3$ & $2,412.7$ & 624.4 \\
\hline $\mathbf{2 0 1 0}$ & $8,247.8$ & $3,405.9$ & $2,955.3$ & 659.6 \\
\hline $\mathbf{2 0 1 1}$ & $8,673.90$ & $3,692.50$ & $3,407.80$ & 886.0 \\
\hline $\mathbf{2 0 1 2}$ & $10,314.0$ & $3,135.5$ & $4,287.8$ & $1,094.5$ \\
\hline $\mathbf{2 0 1 3}$ & $10,540.9$ & $2,655.8$ & $4,935.2$ & $1,041.0$ \\
\hline
\end{tabular}

Source: The State Statistical Committee of the Republic of Azerbaijan (2014c).

The steady real exchange rate appreciation is another potentially hampering factor for export-oriented FDI in the non-oil sector of the economy. If this real exchange rate appreciation continues at such a pace, it is bound to have a negative impact on the export competitiveness of services and manufacturing in the non-oil sector of the economy. This would be a classical example of the so called "Dutch disease" and might constitute an obstacle for future FDI into services and manufacturing that aims at building a regional/global export platform in Azerbaijan (Günther \& Jinda, 2009: 10). Foreign direct investment remains tightly concentrated in the oil and gas sector, and the attraction of FDI to the non-oil sector remains one of the country's most pressing tasks. However, this is not facilitated by elements of the Dutch disease, such as appreciation of the national currency or pervasive corruption (Bertelsmann Stiftung, 2012: 7). The government has worked hard to reduce the impact of Dutch disease, setting up the State Oil Fund of Azerbaijan to preserve macroeconomic stability and retain oil wealth for future generations. It has also implemented a series of national poverty reduction programs and increased public expenditure in infrastructure development, education and healthcare (International Labour Organization, 2012: 1).

\section{Cost and Benefits of Foreign Direct Investment in Azerbaijan Oil Market}

Foreign direct investment in Azerbaijan oil sector has great benefits for the economy, especially in terms of significant developments at macroeconomic indicators such as rapid increase at GDP. Adding to economic growth, human capital contribution, competition level, technology transfer and management and governance practices are some other benefits of foreign direct investment in Azerbaijan oil sector in Azerbaijan economy. On the other hand, it is found that foreign direct investment in Azerbaijan oil sector results in some minor costs to economy such as crowding out, negative wage spillover, profit repatriation and dual economy effect. 


\subsection{Benefits of Foreign Direct Investment in Oil Sector}

As an oil exporting country, Azerbaijan has benefited from the oil boom over the past years, and the government gained huge amounts of oil income and wealth. These huge numbers are seen in export rates and government revenues as $92 \%$ and $74 \%$, respectively. Due to the decline of oil prices in 2008, Azerbaijan revenues fell down by $35 \%$ in 2009 . To cover for this economic deficiency, the government increased the amount of the yearly transfer from the petrol fund to the government budget around 2 billion USD and was able to overcome economic crises (Quliyev, 2014).

Oil sector is an attraction point of Azerbaijan in terms of foreign direct investment. Despite some bureaucratic obstructions, unhealthy investment area and infrastructure constraints, foreign direct investment in oil sector continued to grow (Economic Intelligence Unit, 2012). On the other hand, many investors and authorities from Azerbaijan claim that Azerbaijan there is a quality infrastructure, political stability, plenty of resources, Azerbaijan`s hospitality and being crossroads of Europe and Asia and all those make it easy to invest in Azerbaijan. Economic indicators make Azerbaijan authorities right as there has been a gradual increase at foreign direct investment in oil sector (Azam, 2010 and 2012).

\subsubsection{Foreign Direct Investment and Economic Growth}

There is a positive relationship between economic growth and foreign direct investment. That relationship is important for both developing and developed countries. Economic growth of host country is directly affected by FDI. New job opportunities, inflow of technology, managerial know-how, marketing skills and many other aspects are developed in host country thanks to experiences of foreign investors (Gürsoy, Sekreter \& Kalyoncu, 2013: 519).. Not only stabilization macroeconomic development, but also huge flows of foreign direct investment are elements triggering growth in Azerbaijan economy.

According to Hübner (2011), there is a positive correlation in Azerbaijan between foreign direct investment and economic growth. The author expresses that there is a huge inflow of foreign direct investment to Azerbaijan oil sector. Moreover, that amount of huge flow results in being a catalyst for many other sectors. For example, finance, transportation, construction and many other sectors are directly affected from foreign direct investment to Azerbaijan oil sector. Investment promoting agencies and government in Azerbaijan are proud of declaring that they paced a great development in terms of economic growth. They also express pride about their success of attracting foreign direct investment. It is seen that the sharp economic growth in Azerbaijan economy in the first decade of 21 st century is affected from the amount of foreign direct investment in oil sector (Hübner, 2011: 3).

Gürsoy et al. (2013) studied the relationship between foreign direct investment and GPD. This study investigates the causality between FDI and GDP by using Granger causality test for Azerbaijan, Kyrgyz Republic, Kazakhstan, Tajikistan, Turkmenistan, and Uzbekistan over the period 1997-2010. The ADF unit root test results indicated that Kyrgyz Republic, Kazakhstan, Tajikistan, and Uzbekistan have different orders of integration. Therefore, Johansen Cointegration test is applied to Azerbaijan and Turkmenistan. After finding a 
long-run cointegration relationship, the authors investigate causal relationship using Grager causality test. It is found that FDI Granger causes GDP in the case of Azerbaijan. Therefore, in the case of Azerbaijan, unidirectional causality exists (Gürsoy, et al., 2013: 523).

During 2009, there was an optimistic economic growth at Azerbaijan economy. The reason for that optimistic prediction was smooth performances in the oil sector. In spite of the global financial crisis and low global oil price, Azerbaijan's economy saw relatively significant growth. Both 2008 and 2009 were years of success in Azerbaijan's economy. One of the main reasons for this success was investment in the oil sector. There was a great decrease in many other sectors. There was a decrease of 3.5 percent in agriculture sector as a result of expensive inputs, water storage in agriculture areas, low credit facility and focusing on wheat production solely. Moreover, there was a decrease at oil export as well. Both oil export and oil machinery import decreased in that term. On the other hand, there was a great governmental support and State Oil Fund made a high degree of public investment (Azam, 2012).

Investment in the oil sector in Azerbaijan affects many aspect of economy. For example, foreign direct investment in the oil sector makes oil export rates higher. That has resulted in high development of the reserves of Azerbaijan, especially after 2006. The importance of oil export for reserves can be understood by observing amount of reserves in 2006 and 2008. In 2006, there was a great increase at reserves of the country. There was an increase of 51.4 percent at reserves in 2008 and it reached 6.5 billion USD. However, decline of oil export resulted in a decrease of reserves. There was a decrease of 15.7 percent in 2009 and reserves decreased to 5.18 billion USD. Moreover, there is an amount of 14.2 billion USD in the State Oil Fund, meaning no problem about liquidity. At the beginning of 2013, the reserves in Azerbaijan reached 29.1 billion USD and 22.7 billion USD of that amount belongs to State Oil Fund (DEIK, 2013: 16).

\subsubsection{Human Capital Contribution}

Human capital contribution is one of the important benefits of foreign direct investment to Azerbaijan. FDI makes a significant contribution to the host country about human capital. Operations of foreign investors in the country provide benefit to the country both by decreasing the unemployment and increasing the number of experienced workers. In Azerbaijan oil sector foreign investors are giant international companies with high level of experience and they transfer their experience to the national staff, resulting in well trained staff. Work environment, wages and benefits of foreign investors make oil sector more attractive to work. FDI companies make regular training programs to their employees and transfer the experience to the staff via that way.

Despite the education level and high literacy level, Azerbaijan faces well-trained staff in different business areas. There is a need for engineers with a high level of skill and technologically advanced in different fields of business life. Foreign investment is a good tool in Azerbaijan for training people. At the same time, Azerbaijan is a country where companies spent less than in all other transition countries on research \& development (R\&D). Therefore, per-capita foreign direct investment should be coupled with policies designed to facilitate the 
transfer of knowledge and technology between firms. The government could also set incentive schemes for companies to invest more in its staff (education and vocational training) and in R\&D (Hübner, 2011: 4).

In 2006, Azerbaijan Government prepared its "State Program on study of Azerbaijani youth in abroad in the years of 2007-2015" (Ministry of Education of Azerbaijan Republic, 2009). Up to 2015, Azerbaijan Government aimed to send 5,000 students abroad per year. In the program's last five years, it is seen that only 1,228 students were sent abroad per year. There is still a need to send 3,772 students to abroad in accordance with the program targets (Economic Research Centre, 2010; Begin Group, 2014). At that point, it must be mentioned that there is not the expected amount of students going abroad directly for oil sector. The main countries hosting those students are Germany, Russia, Great Britain and Turkey. According to the statistics of the years 2010-2011, 40.8\% of 2,055 of Azerbaijani students have studied in Turkey, 24.7\% in Russia, 6.6\% in Great Britain, 5.4\% in Germany (Begin Group, 2014).

Considering the oil sector, BP has a role of supporting human capital in Azerbaijan with the Community Investment Program (CIP) starting from 2002. One of CIP's projects was the Sangachal Terminal Expansion Program, aimed to enhance the capabilities of the local workforce. At the end of 2013, the number of national employees increased by 3,216 (85\%) were BP's professional staff. BP signed cooperation agreements with the State Oil Company of the Republic of Azerbaijan (SOCAR) to work together to nationalize BP's staff. The aim of this cooperation is to develop professionals specializing in petroleum disciplines. BP and its co-ventures help fund a lot of educational programs, aimed at training workers in the skills and capabilities that oil industry will need in the future. BP and its co-ventures have been supporting students with oil and gas scholarships since 2002. This program gives Azerbaijan students a chance to continue undergraduate and graduate studies in engineering and geosciences at universities in Turkey and Azerbaijan (BP, 2013).

On the other hand, Yildirim and Tosuner (2014) examined FDI and level of education methodology for 1991-2011 in Azerbaijan, Uzbekistan, Kazakhstan, and Kyrgyz Republic and could not find evidence that FDI supported the level of education in these republics. But they also pointed out the contribution of the multinational companies (MNC) to the human capital. MNCs generally promote tertiary education through sponsorship scholarship to talented/gifted students, which they need for a qualified future workforce (Yildirim \& Tosuner, 2014).

\subsubsection{Competition Level}

Competition level has significant importance for development of a country. Productivity, innovation, lower prices and many other factors make an economy strong. Foreign direct investment supports all those aspects in an economy. Foreign direct investment contributes to both factor productivity and income growth in host countries, beyond what domestic investment normally would trigger. It is more difficult, however, to assess the magnitude of this impact, not least because large foreign direct investment inflows to developing countries often coincide with unusually high growth rates triggered by unrelated factors (OECD, 2002: 
9).

In Azerbaijan, the main foreign direct investment sector is still oil. It takes nearly two-thirds of total foreign direct investment. It is seen that there is an increasingly competitive environment in the oil sector. Especially BP, a United Kingdom energy company, makes investments in the Shafaq-Asiman gas field and that investment has triggered many other investments from other giant companies (OECD, 2002: 192).

Governments have some duties to develop foreign investment in order to increase competition level. The banking sector is a good starting point for this. In Azerbaijan, to establish a more competitive environment, the government should support a national banking system. It should actively promote mergers and acquisitions among banks, especially with the participation of foreign investors. If such reforms are successful, access to finance for entrepreneurs at all levels (in general and especially in the form of better loan conditions) would improve (Hübner, 2011: 4). After increases in foreign direct investment, not only the banking sector but some other sectors would face competition. For example, the agriculture sector needs competitive environment. Increasing foreign direct investment is expected to increase competitive level at agriculture industry (OECD, 2002: 192).

\subsubsection{Management and Governance Practices and Technology Transfer}

Globalization and regionalization are two important processes characterizing the present state of world development. Azerbaijan has been confronting them with great effort. Using its important geographical location and well-educated workforce, Azerbaijan has tried hard to renew the Silk Road and Europe-Caucasus-Asia transport corridor (TRACECA) located in Baku sponsored by European Union. The country is aware of the fact that management and governance practices contributes to an economy's great experience and new management and governance perspectives.

Azerbaijan is ready to play a connecting role in realization of prospective transregional projects, encouraged by international organizations. Cooperation within the framework of international organizations constitutes one of the most significant guidelines of Azerbaijan's foreign economic policy. Azerbaijan is a member of more than twenty international economic organizations and has observer status at the World Trade Organization (OECD, 2001: 3).

In Azerbaijan, increasing foreign direct investment forces local companies to develop their technology and transfer technology from investing companies. To compete with more qualitative foreign goods at the domestic market, local companies have to apply better technologies. This is impossible without FDI and cooperation with leading MNEs on equity and non-equity basis. Local companies acquiring advanced technologies and joint ventures can replace import needs more effective manner. This is also could be justification and necessary step for further export oriented manufacturing (Pashayev, 2013).

According to Hübner (2011), in a diversified environment, foreign direct investment can contribute to broad know-how and technology transfer, inclusion into the global economy, and the development of the financial sector as one of the preconditions for further economic stimulation. It usually contributes to wealth and job creation. And it can have an impact on 
educational levels and increase skills among the working population through training and investments in research and development (Hübner, 2011: 3).

In Azerbaijan, increasing FDI has led to some developments and projects in terms of technology transfer. Some of those projects are as follows (Dobrinsky, 2012):

- World Intellectual Property Organization (WIPO) was requested to organize by the State Committee on Standardization, Metrology and Patents of the Republic of Azerbaijan in cooperation with the Committee a Regional Seminar on Technology Transfer Issues.

- The Center for Technology Transfer has been established at the Azerbaijan State University of Economics.

- AzDRES Energy Efficiency Improvement Project.

- Sumgait Technologies Solar Park.

- Demonstration project of hydroelectric power plant.

\subsection{Costs Foreign Direct Investment in Oil Sector on Economy}

\subsubsection{Crowding Out}

For a long time, it has been a significant debate whether foreign direct investments damage the economy of the host country by crowding out domestic investment. There may be several factors influencing the ability of domestic investors during their competition with foreign rivals. First, it is difficult for domestic investors to compete with foreign investors without a high level of technology and efficient operation (Acar, Eris \& Tekce, 2013:2). Foreign investors in oil sector are giant companies operating globally with giant budgets and technology know-how.

In general, FDI does crowd out domestic investors, especially in the short term. Arbitrage and FDI take advantage of government incentives and tend to concentrate on traditional rather than high-tech industries. Because private enterprises often concentrate in traditional industries, FDI can cause crowding. In private enterprises engaged in centralized and highly competitive manufacturing applications, this kind of crowding out was obvious (Wu, Sun \& Yu, 2012: 1). Weak financial intermediation hits domestic enterprises much harder than it does multinational enterprises (MNEs). In some cases, it may lead to a scarcity of financial resources that precludes them from seizing the business opportunities arising from the foreign presence (OECD, 2002: 10).

Farla, de Crombrugghe, and Verspagen (2013) prepared a study about this crowding-out effect in some countries including Azerbaijan. The end of the study showed that effects of FDI vary during different situations. In general, it is difficult for domestic investors to struggle with giant companies.

On the other hand, Clemens (2008) argues that the crowding out effect in the oil sector of the Azerbaijan economy is not important. A higher capital inflow from abroad is an external 
increase in capital stock with no influence on the consumption and saving decision. Thus, the level of capital rises, but the steady-state value does not change (Clemens, 2008: 23).

According to Lerman and Sedik (2010), foreign direct investment in the oil sector is not crowding out other sectors. However, those sectors do not perform as well as the oil sector. One of the main reasons for that can be seen as the amount of people working in oil sector and other sectors. Comparing with many other oil-producing countries, Azerbaijan does not employ as many people as others (Lerman and Sedik, 2010: 58).

\subsubsection{Negative Wage Spillover}

Negative wage spillover is another important problem caused by foreign investors. As described above, giant companies in oil sector have giant budgets and they are able to work with qualified staff as a result of high salaries. Because of this, domestic firms hire lower-quality staff. This situation results in many undesirable situations in productivity and operations (Lipsey and Sjöholm, 2004: 3).

On wage spillovers, Görg and Greenaway (2001) reported that panel data showed negative spillovers, but cross-sectional data showed positive ones. The same paper found, with respect to productivity spillovers from foreign-owned to domestically owned firms, only limited evidence in support of positive spillover. Most work fails to find positive spillovers, with some even reporting negative spillovers (Görg and Greenaway, 2001).

Azerbaijan has recently started to be discussed about negative wage spillover effects of foreign direct investment. However, this situation may be discussed in two ways. While negative wage spillover is harmful for domestic investors, it is good for people working in the country (Pamukcu and Taymaz, 2009: 3).

\subsubsection{Profit Repatriation}

Profit repatriation has always been an important topic for investors during foreign investment choices. Companies always want to be able to take their money back home for several reasons. For example, they want to be able to take their money back home when there is any kind of instability in the host country. To attract foreign investors, countries are to make some measures about that topic. The conclusion offers an interesting idea for developing countries that seeks to attract FDI inflow and always allows free repatriation. This kind of point must be taken into account by policy makers. However, FDI may result in other benefits such as technology spillover or employment generation (Markusen, 1984).

Foreign investors generally focus on investment opportunities. For example, changes in macro and micro economic indicators among the countries change investment plans and applications. Companies are eager to have alternatives in various situations. While an economic situation in a country may make an investor invest in that country; better opportunities in another country may attract the investor more. Under those circumstances, investors want freedom (Lundan, 2006: 42). Azerbaijan government gives investors a guarantee of free profit repatriation (HLB, 2011).

According to World Bank (2014), Azerbaijan has a deficit in net income from abroad, 
essentially because of profit repatriation by foreign oil companies. Oil- and gas-related FDI inflows narrowed the deficit on the capital account by 5\% in the third quarter of 2013 compared with the same period in 2012. The ongoing investments to halt the decline in oil production, along with new investments in the Shah Deniz gas field, increased FDI inflows (World Bank, 2014: 36).

\subsubsection{Dual Economy Effect}

For some countries, it may be unavoidable to face a so-called dual economy during foreign direct investment inflows. Especially in an underdeveloped economy, when host sectors show great development as a result of FDI, the dual economy effect arises. However, FDI does not affect the general growth of the country (Stanisic, 2008: 30).

Because Azerbaijan has been a good investment direction for investors in terms of its oil sector, it may be expected to see a dual economy effect. The country is a good market for investors because of its economic and politic stability. Up to recent years, it has been observed that a dual economy effect was active in the country because of investment in oil and construction sectors. Even today, despite the increase of non-oil sector, there is a lack of employment, tax, and export at other sectors (ESO, 2013).

For the time being, it would be highly doubtful to assume that Azerbaijan could survive at its current economic level without reliance on the oil and gas industry. While no changes are needed immediately, the country cannot count on the fossil fuel sector in the mid-to long-term perspective (Hübner, 2011: 3).

\subsubsection{Other Costs of Foreign Direct Investments}

Another negative consequence of FDI is seen at problems seen at balance of payment. According to Accoley (2003), the impact of FDI on trade, i.e., exports and imports, is ambiguous. A horizontal FDI, for instance, theoretically induces a decrease in the host country's imports and, ceteris paribus, an improvement of its trade balance. This prediction may not hold true if the inputs used by the foreign-owned firm are imported from abroad. Furthermore, an FDI consisting of selling in the host country goods manufactured abroad, i.e., a vertical integration forward, will increase the home country's imports. An FDI aiming at extracting minerals or producing component parts may positively impact the host country's visible balance (Accoley, 2003: 19).

There are some other negative effects of foreign direct investments (Accoley, 2003: 21):

- Foreign direct investment may result in some unexpected problems that are hard to measure. For example, political, social, structural and environmental disorders may be observed in the country.

- The great majority of countries want to preserve their cultural properties. FDI activities of giant firms may result in active participation in mass media, changing the cultural properties of the society.

- FDI in manufacturing and mining sectors in developing countries can be the source of 
negative externalities affecting the local environment, e.g., pollution of air and rivers.

\section{Suggestions}

To reach targets and achieve better economic results in both other sectors and the oil sector, the Azerbaijan government should take some steps. First, it must develop the benefits of FDI in oil sector. Secondly, it must try hard to get rid of that FDI's costs.

As mentioned, Azerbaijan has a list of incentives for foreign investors. Those incentives must be enhanced and problems must be solved. For example, foreign investors need more support in human capital. They also want to rely on economic and politic condition of the country. Azerbaijan may take steps to explain that it has a stable economy. Moreover, there may be organizations in different forums and countries to provide better information for potential investors.

Another important point to be discussed is competition level. Competition in a sector provides great benefits. According to a study of European Commission (2012), benefits of competition can be listed as follows:

- Low prices for all: The simplest way for a company to gain a high market share is to offer a better price. In a competitive market, prices are pushed down.

- Better quality: Competition also encourages businesses to improve the quality of goods and services they sell - to attract more customers and expand market share.

- More choice: In a competitive market, businesses will try to make their products different from the rest.

- Innovation: To deliver this choice, and produce better products, businesses need to be innovative - in their product concepts, design, production techniques, and services.

- Better competitors in global markets: Competition makes companies stronger.

All those reasons demonstrate that Azerbaijan must get rid of hegemony of some well-known firms. Government must promote all companies in the sector regardless of their nationality. In other words, both foreign investors and national investors must be supported.

Azerbaijan must also minimize the costs of foreign direct investment. As described above, an important cost of foreign direct investment on oil sector in Azerbaijan is crowding out. In general, it is seen that foreign direct investments crowd out domestic investors, especially in the short term. Arbitrage and foreign direct investment took advantage of government incentives and tended to concentrate in traditional rather than high-tech industries. Because private enterprises often concentrate in traditional industries, foreign direct investment can cause crowding. In private enterprises engaged in centralized and highly competitive manufacturing applications, this kind of crowding out was obvious (Wu, Sun \& Li, 2012: 1).

To minimize it, small firms in the country must be supported, especially if their capital and know-how capacity is low. Therefore, the government may need to support regional investors in terms of money and experienced workers. For example, some experienced workers may be 
encouraged to work in regional firms by the government itself. This is also important to minimize negative wage spillover.

In fact, Azerbaijan must take some steps to address its dual economy and profit repatriation. It is not difficult to solve problems caused by those factors. However, both academics and politicians must think about their effects. The following remedies may be suggested for Azerbaijan:

- Better advertisement,

- Apprenticeship in multinational oil firms,

- Supporting competition,

- Investing not only capital but also technology,

- Supporting national firms in terms of crowding out (via encouraging skilled workers to work in regional firms),

- Supporting regional firms in terms of wages.

\section{Conclusion}

This study demonstrates some important points about FDI and its effect on the Azerbaijan economy considering foreign direct investment seen in oil sector. First of all, FDI is an activity having great contributions for host country. It is usual to see that a country getting the attention of foreign investors and getting high amount of foreign direct investment is likely to develop in a short period of time. That kind of development is supported by high inflow seen during foreign direct investment processes, decreased levels of unemployment, increased export rates, and increased revenues.

Azerbaijan has had a sharp increase of economic indicators. There is significant development at inflation rates, gross domestic product, reserves, and employment rates. Although the country was an oil dependent economy fifteen years ago, there is an increase at non-oil sectors as well. Agriculture, tourism, construction, trade, service, transport, communication and financial service are some of the sectors in Azerbaijan having high levels of development especially in the last decade. Thanks to the development of non-oil sectors and especially the oil sector, there is a gradual increase of export rates. As a result of buying technological machinery, there is also an increase at import level. However, high levels of export of crude oil and gas makes export rates higher than import level. There are a great deal of reserves in the country. Moreover, reviewing the literature shows that academicians, economics and many organizations estimate that Azerbaijan economy will continue to develop in the future. By the year 2020, people estimate that Azerbaijan will be one of the most important economies in the world.

There may be several reasons for economic development in Azerbaijan. However, an indicator shows similar trends with statistical data about the development of Azerbaijan economy. It is the amount of foreign direct investment seen in the country. The Azerbaijan economy started to develop especially after the beginning of 2000s. The amount of FDI in the 
country increased at the same time. Moreover, FDI in Azerbaijan mainly focuses on the oil sector. The more FDI in the oil sector mean the more developed macroeconomic indicators in the country. Consequently, it is easy to claim that foreign direct investment in oil sector has positive effects on Azerbaijan economy.

Since there is a positive correlation between foreign direct investment and economic growth, Azerbaijan must promote FDI in the oil sector. As described previously, foreign direct investment in Azerbaijan oil not only has positive effects on macroeconomic indicators, it also has effect on many other aspects of economy. For example, human capital contributions, competition level, management and governance practices and technology transfers are other benefits of foreign direct investment in Azerbaijan oil sector on Azerbaijan economy. On the other hand, there are also some problems faced as a result of foreign direct investment in oil sector. Crowding out, negative wage spillover, profit repatriation and dual economy effect are costs of foreign direct investment in Azerbaijan oil sector to Azerbaijan economy. All in all, it is easy to say that foreign direct investment in oil sector has great benefits for the Azerbaijan economy.

Another important point is technology transfer. As an important benefit of foreign direct investment, Azerbaijan must try hard to benefit from investors' expertise, capability and technology, and transmit them within the country.

Azerbaijan is a developing country. All developing countries face some similar problems. One of those problems is an unskilled workforce. Thanks to foreign direct investment in the oil sector, Azerbaijan is developing young, skilled workers. Those people work in multinational firms and gain a great deal of experience thanks to those firms. As a result, those people may work further at other companies and even for the government. Azerbaijan can use that advantage in a good way. Firstly, Azerbaijan universities must pay more attention to facilities concerning the oil sector. Secondly, those students must work in multinational firms as apprentices for a long time before graduating from university. Thanks to working in those firms, they will be able to learn many things about the business. That situation results in good benefits both for investors and Azerbaijan itself.

Lastly, there is a shortage of studies about negative effects of FDI in Azerbaijan economy. The previously mentioned costs of FDI to the Azerbaijan economy or oil industry must be studied in great detail and suggestions must be prepared to get rid of or diminish these costs.

\section{References}

Acar, S., Eriş, B., \& Tekçe, M. (2013). The Effect of Foreign Direct Investment on Domestic Investment: Evidence from MENA Countries. European Trade Study Group (ETSG) 14th Annual Conference

Aras, O.N., \& Süleymanov E. (2012). Azerbaycan'in Enerji Kaynaklari Gelirlerinin İhrac Hacmindeki Yeri ve Ülke Ekonomisine Etkisi, Proceeding Book of International Conference on Eurasian Economies: 225-232. [Online] Available: http://www.eecon.info/papers/464.pdf

Azam, M. (2010). Economic Determinants of Foreign Direct Investment in Armenia, Kyrgyz 
Republic and Turkmenistan: Theory and Evidence. Eurasian Journal of Business and Economics, 3(6), 27-40.

Azam, M. (2012). The Determinants of Foreign Direct Investment: Evidence from Azerbaijan and Kazakhstan. Central Asia Journal 67. [Online] Available: http://www.asc-centralasia.edu.pk/Issue_67/03_Muhammad_Azam.html

Begin Group. (2014). Azeri Government Supports Students to Study Abroad, A study of Begin Group. [Online] Available: http://begingroup.com/en/top/press_office/reports/1361 (18.08.2014).

BP. (2013). BP in Azerbaijan Sustainability Report 2013. [Online] Available: http://www.bp.com/content/dam/bp/pdf/sustainability/country-reports/BP_Azerbaijan_sustain ability_report_2013.pdf

Bertelsmann Stiftung. (2012). Azerbaijan Country Report, Bertelsmann Stiftung's Transformation Index, [Online] Available: http://www.bti-project.de/fileadmin/Inhalte/reports/2012/pdf/BTI\%202012\%20Azerbaijan.pd $\mathrm{f}$

Bureau of Economic and Business Affairs. (2013). 2013 Investment Climate Statement Azerbaijan, March 2013 Report of Bureau of Economic and Business Affairs

Center for Energy Economics (2003), Oil Monetization in Azerbaijan, Texas: Center for Energy Economics, [Online] Available: http://www.beg.utexas.edu/energyecon/new-era/case_studies/Oil_Monetization_in_Azerbaija n.pdf

Ciarreta, A., \& Nasirov, S. (2012). Impact of Azerbaijan's Energy Policy on the Development of the Oil Sector, International Association for Energy Economics

Clemens M. (2008). Azerbaijan between Resource Curse and Foreign Direct Investments. [Online] Available: http://www.essadbey.de/pdf/Marius_EB_FDI.pdf (01.09.2014).

DEIK. (2012). Azerbaycan Ülke Bülteni, Dış Ekonomik Ilişkiler Kurulu

Delali, A. (2003). The Determinants and Impacts of Foreign Direct Investment, MPRA Paper No. 3084

Dobrinsky, R. (2013). The National Innovation System of Azerbaijan in the Context of Effective Development and Diffusion of Green Technologies. Joint National Seminar and Stakeholder Meeting on Promotion and Financing of Innovative Green Technologies Ways to Greening the Industry

Economic Research Centre. (2010). Research report on "State Program for education of Azerbaijan youth abroad in the years of 2007/2015," Research Paper of Economic Research Centre

EIA. (2013). Countries Azerbaijan. [Online] Available: http://www.eia.gov/countries/analysisbriefs/Azerbaijan/azerbaijan.pdf (01.07.2014). 
Economic Intelligence Unit (2012), Azerbaijan, [Online] Available: http://country.eiu.com/azerbaijan (16.08.2014).

Festervand T. A. (2011). Perceptions of Select, Newly Established Nations of the Former Soviet Union as Foreign Direct Investment Options: A Longitudinal Perspective, International Business \& Economics Research, 10(6), 9-20.

Frayne, T. (2012). Energy Sector FDI in Azerbaijan: An Example of Good Governance?, [Online]

Available: http://www.e-ir.info/2012/08/05/energy-sector-fdi-in-azerbaijan-an-example-of-good-govern ance/

Görg, H., \& Greenaway, D. (2001). Foreign Direct Investment and Intra industry Spillovers: A Review of the Literature, Globalisation and Labor Markets Programme, Research Paper No. 2001/37. Nottingham, U.K.: Leverhulme Centre for Research on Globalisation and Economic Policy.

Günther, J., \& Jindra, B. (2009). Investment (FDI) Policy for Azerbaijan, IHW, Halle Institute for Economic

Gürsoy, F., Sekreter, A., Kalyoncu, H. (2013). FDI and Economic Growth Relationship Based On Cross-Country Comparison. International Journal of Economics and Financial Issues 3 (2), 519-524

Hübner, G. (2011). Foreign Direct Investment in Azerbaijan - the Quality of Quantity, Caucasus Analytical Digest (28), 2-13. [Online] Available: http://www.css.ethz.ch/publications/pdfs/CAD-28-2-6.pdf

HLB (2011). Doing business in Azerbaijan, London: HLB Azerbaijan LLC, [Online] Available:

http://www.hlbi.com/index.php?option=com_k2\&view=item\&task=download\&id=13_3736f c624342d4e5c87c743a05850627.

Ilgun, E, \& Coskun, A. (2009) Foreign Direct Investments In Bosnia And Herzegovina: Bankıng Sector Example. Alatoo Academic Studies 4 (2): 49-67.

International Labour Organization. (2012). Country Profile of Azerbaijan, Decent Work of International Labour Organization, [Online] Available: http://www.ilo.org/wcmsp5/groups/public/---dgreports/---integration/documents/publication/ wcms_175754.pdf

Information Digest. (2007). Azerbaijan, Information Digest

Lerman, Z., \& Sedik D. (2010). Rural Transmission in Azerbaijan. Lexington Books

Lipsey, R. E., \& Sjöholm, F. (2004). Host Country Impacts of Inward FDI: Why Such Different Answers, Working Paper No 192

Lundan, S. M. (2006). Reinvested earnings as a component of FDI: an analytical review of the determinants of reinvestment, Transnational Corporations, 15(3), 35-66. 
Markusen, J.R. (1984). Multinationals, Multi-plant Economies, and the Gains from Trade, Journal of International Economics, 205-226. http://dx.doi.org/10.1016/S0022-1996(84)80001-X

Ministry of Education of Azerbaijan Republic. (2009). [Online] Available: http://www.edu.gov.az/view.php?lang=en\&menu=135

OECD. (2001). New Horizons and Policy Challenges for Foreign Direct Investment in the 21 st Century, OECD Global Forum On International Investment, Mexico City, Mexico

OECD. (2002). Foreign Direct Investment for Development Maximising Benefits, Minimising Costs, OECD

Pamukcu, T., \& Taymaz, E., (2007). Testing for Wage Spillovers to Uncover Human Capital Transfers from Foreign to Domestic Firms in the Turkish Economy. ERF 14th International Annual Conference, Cairo.

Pashayev, F. (2013). Investment policies and competitiveness of Azerbaijani economy. Khazar Journal of Humanities and Social Sciences, 16(2), 22-31. http://dx.doi.org/10.5782/2223-2621.2013.16.2.22

Quliyev F. (2014). Neft qiymətlərinin düşməsi Azərbaycan üçün niyə pis xəbərdir BBC. [Online] Available: http://www.bbc.co.uk/azeri/azerbaijan/2014/08/140829_oil_prices_fall.shtml (Accessed on 15.02.2015).

Rosenblum, S. (2011). How serious is Azerbaijan s Anti-Corruption Campaign, Central Asia-Caucasus Analyst, http://old.cacianalyst.org/?q=node/5506

The State Statistical Committee of the Republic of Azerbaijan. (2014a). GDP production in the section of oil and non-oil of economy, The State Statistical Committee of the Republic of Azerbaijan

The State Statistical Committee of the Republic of Azerbaijan. (2014b). Exports of main commodities in 2013 (by countries), The State Statistical Committee of the Republic of Azerbaijan

The State Statistical Committee of the Republic of Azerbaijan. (2014c). Foreign Investments (mln US Dollars), The State Statistical Committee of the Republic of Azerbaijan

World Bank (2012). Azerbaijan - country economic memorandum - new silk way diversification at the account of export. World Bank Report No. 44365-AZ.

World Bank. (2014). Azerbaijan Partnership Program Snapshot, April 2014. [Online] Available: www.worldbank.org/en/country/azerbaijan (Accessed on 10.08.2014).

Wu, G., Sun, Y., \& Li, Z. (2012). The Crowding-In and Crowding-Out Effects of FDI on Domestic Investment in the Yangtze Delta Region, China: An International Journal 10(2):119-13 


\section{Macrothink}

Asian Journal of Finance \& Accounting ISSN 1946-052X 2015, Vol. 7, No. 1

World Energy Council. (2013) World Energy Resources 2013 Survey. [Online] Available: http://www.worldenergy.org/wp-content/uploads/2013/09/Complete_WER_2013_Survey.pdf

Yildirim, D.C., \& Tosuner, O. (2014) The Effects of FDI on Human Capital Stock in Central Asian Turkic Republics, Eurasian Journal of Business and Economics, 7(14), 51-60. http://dx.doi.org/10.17015/ejbe.2014.014.03

\section{Copyright Disclaimer}

Copyright for this article is retained by the author(s), with first publication rights granted to the journal.

This is an open-access article distributed under the terms and conditions of the Creative Commons Attribution license (http://creativecommons.org/licenses/by/3.0/). 